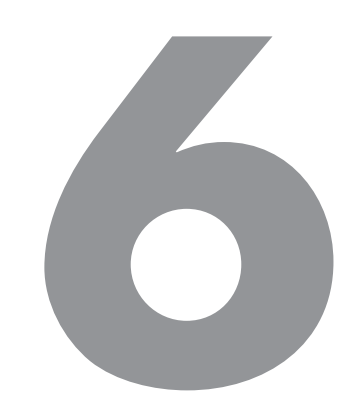

\title{
PROCESSO SINCRÉTICO APLICADO À RESCISÓRIA
}

As reformas processuais das últimas décadas introduziram e fortaleceram no sistema positivo o chamado processo sincrético. ${ }^{1}$

Em síntese, o processo sincrético permite compartilhar no processo de conhecimento técnicas que seriam próprias do processo de execução, máxime após a introdução da tutela antecipada (espécie de tutela de urgência) e a previsão da fungibilidade do art. 305, parágrafo único, do cumprimento de sentença (art. 523) e da tutela das obrigações de fazer e não fazer (tutela inibitória), conforme o art. 497, todos do CPC/2015. ${ }^{2}$

1 No processo sincrético, o juiz exara a sentença e, após o seu trânsito em julgado, passa a promover o seu cumprimento, não sendo necessária a instauração de uma nova relação processual. (DESTEFENNI, Marcos. Curso de processo civil. 2. ed. São Paulo: Saraiva, 2010. v. I, t. 2, p. 312).

2 Com o advento da Lei n. 11.232/2005, o legislador adotou o processo sincrético no ordenamento processual pátrio. Alterou-se a natureza jurídica da execução fundada em título executivo judicial, que passou de processo autônomo a fase do processo, adotando-se o processo sincrético, eis que reunidos no mesmo processo os atos cognitivos e os executivos. Confira-se na doutrina: CÂMARA, Alexandre Freitas. A nova execução de sentença, p. 89. 
Em verdade, o processo sincrético não é infenso ao regime da ação rescisória, podendo ser manifestadas as providências cautelares e até aquelas próprias do rito executório, dentro do processo de conhecimento instaurado pela ação rescisória. O exemplo patente é a aplicação da tutela antecipada fora do cunho meramente assecuratório da tutela principal, concedendo-se a antecipação do pedido rescisório (v.g., rejulgamento da causa) e, assim, propiciando a execução que dela pode decorrer, em função da anterior improcedência do pedido e que agora passa a ser reconhecido tal direito pelo Poder Judiciário; seja para ingresso em internação hospitalar contra plano de saúde, seja fixando verba alimentícia, ou outro caso, em que o direito principal não poderá aguardar o final da ação rescisória e já estejam preenchidos os requisitos. 